\title{
Globalisation, Technology, and Asian Economic Growth
}

\author{
S. M. NASEEM
}

\section{INTRODUCTION}

Although globalisation is by no means a recent phenomenon, ${ }^{1}$ its new wave has raised a number of questions-both about its supposed benefits and its alleged adverse consequences. Rather than exploring the wider ramifications of globalisation, this paper will confine its purview to the question of technology development and dissemination in the context of globalisation as it has affected the development of Asian economies in the last few decades. In particular, the paper will focus on the somewhat dazzling performance of the East Asian economies in the last three decades and their equally sharp and unforeseen downturn in the past two years, which has raised serious doubts first about the replicability and later about the robustness of the East Asian development experience. Although the palpable cause of the current East Asian crisis has generally been situated in the increasing complexity and fragility of the global financial system, many prescient international economists had attributed it to the weakness of the technological underpinnings of East Asian growth [Krugman (1994)]. The East Asian crisis has also raised a lively controversy concerning the impact and desirability of selective micro-economic interventions by national governments, which have often been oversimplified under the rubric of 'crony capitalism'. While the debate on which causes contributed most to the sudden down-turn in the growth of the East Asian economies remains inconclusive, there seems considerable validity in the conjecture that their future growth prospects will depend on their ability not only to master current technologies, but also to significantly further their technological prowess through R and D and scientific achievement. Although the immediate trigger of the present crisis in East Asia may have been the turmoil in their financial markets, the underlying problems in the real economy, which have so far received insufficient attention, stem largely from their incommensurate technological development.

S. M. Naseem has worked for many years at Economic and Social Commission for Asia and the Pacific, Bangkok, Thailand.

${ }^{1}$ For a historical review, see Nayyar (1996). 
Technological factors which played second fiddle to capital accumulation in economists' explanation of economic growth in the past, have increasingly taken a centre stage, especially in the analysis of long-term growth trends [Martin and Pavitt (1993) and OECD (1992)]. Globalisation itself owes both its origin and recent resurgence in no uncertain way to the spurt of technological innovations which have expanded its reach in all possible directions. The late 19th century witnessed, among other things, the opening of the Suez Canal, the completion of the Union Pacific railroad and the laying down of submarine telegraph cables across the Oceans, making it possible to conduct the free flow of goods and services, as well as of information, across the globe. The current wave of innovations in electronic technology has, of course, multiplied manifolds the speed with which these flows now moved globally. Indeed this speed is a rather mixed blessing and has given rise to considerable volatility in world capital and foreign exchange markets which was partly responsible for the recent East Asian debacle.

The paper is organised in the following manner. After a preliminary indication of the scope of the paper in the present section, the paper discusses the relationship between globalisation and economic growth from the perspective of technological change. Section III takes stock of growth in the Asian region, concentrating on the two major subregions, East Asia and South Asia, which not only constitute the bulk of population and income of the region, but also provide an interesting contrast in their development experience, including their policies towards technological and human development. The fourth section of the paper reviews the role of technology in development strategies followed over time and across countries. The fifth section focuses on the impact of globalisation on technology development and dissemination. The sixth section of the paper discusses the role of technology in explaining the both the spectacular rise and the present crisis of East Asian economies. The concluding section tries to draw some lessons from the experience of Asian developing countries from technological development in the present era of globalisation.

\section{GLOBALISATION AND ECONOMIC GROWTH}

World merchandise trade has grown by a factor of 16 in real terms since 1950, while world real output grew by a factor of 5.5, reflecting the increasing openness of economies. And the pace of trade integration appears to be accelerating. During the period 1985-1996 the ratio of trade to world GDP rose three times faster than in the previous decade. Services trade has been one of the fastest-growing components of this trade. Similar trends are observable in foreign direct investment and technology transfers.

However, despite the euphoria about globalisation some of the largest economies, like the United States, still remain largely closed to the outside world. In the US economy the share of trade-measured as the average of exports and imports 
of goods and services-in its GDP was less than 5 percent in 1960s and rose to 11.4 percent in 1994, implying more than doubling of the ratio. While growth of trade has not been quite as dramatic in other developed countries it has also been impressive. Thus the trade share of the average OECD countries rose from 12.5 percent in 1960s to 18.6 percent in 1990s. Many developing countries, including China, export 25 to 100 percent of their GDP but it would be wrong and conceitful to suppose that the global economy is a late twentieth century creation. Indeed much of the growth in trade since 1960s simply represents a recovery to the levels achieved before 1913 when the world trade declined substantially as a result of the rise of protectionism which accompanied the rise in aggressive nationalism during the inter-war period.

The pace of globalisation among developing countries, however, has been uneven. Just ten countries contributed more than three quarters of the last decade's rise in the overall developing country trade-GDP ratio. Trade ratios fell in some 44 out of 93 developing countries. The distribution of FDI was also skewed: 8 countries comprising 30 percent of developing country GDP garnered two-thirds of FDI in 1990-93, and half of the countries received inflows of less than 0.2 percent of GDP.

Although the current resurgence in the international trade and investment does not refute the existence of previous eras of globalisation, there are certain inherent features of the globalisation process the world is currently experiencing which differentiates it from those in earlier periods. In some ways the evolving world economic system is the first to be genuinely globalise. Markets in different parts of the world interact continuously. Modern communications enable them to respond instantaneously. Sophisticated credit instruments provide unprecedented liquidity. Hedge funds, the trading departments of international banks and institutional investors possess the reach, power and resources to profit from market swings in either direction, and even to bring them about.

Four characteristics of the present globalise system have often been particularly highlighted. First, the rise of intra-trade or trade in similar goods between similar countries, implying the increasing plurality in the range of goods traded between countries both as exports and imports, rather than the existence of a mutually exclusive pattern of comparative advantage. Secondly, the ability of producers to slice up the value chain, breaking the production process into a number of separate stages which enable the possibility of geographical specialisation. Another significant feature of the present phase of globalisation is the emergence of super exporters, with trade ratios close to 100 percent and large share in international trade. Finally, it has given rise to the emergence of large exports of manufactured goods from low-wage to high-wage nations and the evolution of a new pattern of specialisation between developed and developing countries.

The rapid rise in post-war international trade has been attributed to a number of factors. These include political factors, as well as the emergence of a more 
interdependent global economy under the leadership of United States which became a standard bearer of free trade, notwithstanding the considerable strength of the protectionist lobby in the United States. The conclusion of a number of comprehensive rounds of trade liberalisation under GATT has also contributed to the opening up of world economies during the inter-war period. In addition there were a number of unilateral actions by many developing countries which wished to eschew the earlier strategy of import substitution in favour of export promotion to enable them to benefit from enlarging the size of the market for their products. The rise in world trade is also a result of the changes in political boundaries, which have created new nations and have served to convert internal commodity movements into international trade flows.

While technological change has received a significant role in explaining the growth of world trade, not all technological development can be considered as trade creating. Some observers believe that the major technological innovation facilitating trade such as the rail, road, steam ship and the telegraph were already in place before the two World Wars and that major technological innovations have not been on the same scale of importance in terms of explaining the rise in trade flows [Krugman (1995)]. However, others [Cooper and Srinivasan (1995)] have disputed this and have pointed out the enormous reduction in costs of ocean transportation, particularly, for low value items, such as coal, iron ore and oil in large super tankers, bulk carriers, containerships and roll-on-roll-off, with capacities 15 to 30 times larger than those of pre-World War II ships. Even more significant development has been the emergence of long distance jet airliners and wide- body jets which have made it possible to ship perishable items such as cut flowers, fruits and vegetables across the globe at reasonable transport costs. Cheap air freight also permits the international organisation of production- slicing and subcontracting and combines it with just-in-time production of goods. It has also facilitated the shipment of samples and documents through courier airfreight services. One estimate puts US overseas exports shipped by air freight at 40 percent and of its imports at 30 percent [Cooper and Srinivasan (1995)].

The widespread availability of computers and telecommunications has facilitated the geographic dispersion of a complex production process which were previously very difficult to coordinate. The advent of such innovations such as long range passenger jet, cheap international phone calls, fax machines and electronic mail have permitted an intensity of long distance business interactions that were not previously possible. Against these favourable influences of technology on world trade some possible negative impacts should also be mentioned. Such negative impacts include the miniaturisation of products resulting in much lower use of raw materials per unit value of output and the lower productivity of the non-traded service sector which reduces the share of traded goods in GDP. 
For policy-makers in developing countries, globalisation raises both concerns and policy challenges. Global integration does permit a country to seize the opportunities presented by a favourable external environment, notably the importation of new technology, the more efficient allocation of productive resources, and the reduced cost of capital. However, there are substantial risks in engaging with the global economy for individual countries. It increases their vulnerability to external shocks which have become increasingly frequent since the liberalisation of trade and capital flows. Only countries which can afford to keep substantial foreign exchange reserves or have access to large bail-out packages in the event of a financial crisis or attack on their currency have been able to successfully confront the risks of globalisation. The long-run benefits of increased integration are conspicuously evident through their impact on domestic growth and living standards. Over the last decade per-capita growth in the quartile of fastest integrating developing countries was over 3 percentage points more than in the quartile with the lowest pace of integration.

The degree of globalisation of industry depends more on the characteristics of individual industries than on each country's specialisation. The most globalise manufacturing industries are high- and medium-high-technology: computers, scientific instruments, pharmaceuticals, electronics, basic chemicals, electrical machinery and motor vehicles. The only high-technology industry not to be very globalise is the aircraft industry, which is export-oriented but not extensively directly established in foreign countries. Among the low-technology industries, the most globalise is textiles and clothing.

\section{THE ASIAN GROWTH EXPERIENCE}

The growth performance of the Asian region during the last two decades has been among the strongest in the world economies. Both the East Asian and South Asian sub-regions, which account for the bulk of the population and income of the continent, had high growth rates during the two decades. The growth of East Asia region was stronger, with some countries, such as China and Korea recording double-digit annual growth rates of GDP in some years. China's average growth rate for the entire period between 1980-1997 was above 10 percent while that of Korea was 9.5 percent during 1980-90 but decelerated to 7.2 percent during the 1990-97.

The South-Asian region also recorded a high growth rate of 5.7 percent between 1980 to1997 (See Table 1). However, the disparity between the two subregions in per capita income growth was wider because of the higher rate of population growth in South-Asia. There were also marked differences between the growth of the two sub-regions, as reflected in the differential rates of growth of industry, export of goods and services and gross domestic investment. A major reason for the more vigorous growth of East Asia compared to that of South Asiawas 
Table 1

Growth of Selected Asian Economies, 1980-97

\begin{tabular}{|c|c|c|c|c|c|c|c|}
\hline \multirow[b]{2}{*}{ Economy } & \multicolumn{2}{|c|}{$\begin{array}{l}\text { Gross Domestic } \\
\text { Product }\end{array}$} & \multicolumn{2}{|c|}{$\begin{array}{c}\text { Industry Value- } \\
\text { added }\end{array}$} & \multicolumn{2}{|c|}{$\begin{array}{c}\text { Exports of Goods } \\
\text { and Services }\end{array}$} & \multirow{2}{*}{$\begin{array}{c}\text { Gross Domestic } \\
\text { Investment } \\
1990-97 \\
\end{array}$} \\
\hline & 1980-90 & 1990-97 & 1980-90 & $1990-97$ & 1980-90 & $1990-97$ & \\
\hline Bangladesh & 4.3 & 4.5 & 4.9 & 6.8 & 7.7 & 15.7 & 13.4 \\
\hline India & 5.8 & 5.9 & 7.1 & 7.1 & 5.9 & 13.7 & 8.9 \\
\hline Nepal & 4.6 & 5.0 & 6.0 & 7.7 & 5.6 & 24.1 & 5.2 \\
\hline Pakistan & 6.3 & 4.4 & 7.3 & 5.5 & 8.1 & 4.4 & 3.8 \\
\hline Sri Lanka & 4.2 & 4.9 & 4.6 & 6.5 & 6.8 & 8.4 & 6.4 \\
\hline Indonesia & 6.1 & 7.5 & 6.9 & 10.2 & 2.9 & 9.2 & 10.2 \\
\hline Korea Rep & 9.5 & 7.2 & 12.1 & 7.5 & 12.0 & 15.7 & 6.3 \\
\hline Malaysia & 5.2 & 8.7 & 7.2 & 11.2 & 10.9 & 14.0 & 16.1 \\
\hline Philippines & 1.0 & 3.3 & -0.9 & 3.7 & 3.5 & 11.5 & 5.8 \\
\hline Singapore & 6.6 & 8.5 & 5.4 & 9.1 & 10.8 & 13.3 & 9.8 \\
\hline Thailand & 7.6 & 7.5 & 9.9 & 10.3 & 14.0 & 12.8 & 10.3 \\
\hline China & 10.2 & 11.9 & 11.1 & 16.3 & 11.5 & 16.8 & 14.1 \\
\hline East Asia \& Pacific & 7.8 & 9.9 & 8.9 & 14.5 & 8.8 & 12.7 & \\
\hline Latin America & 1.8 & 3.3 & 1.5 & 2.8 & 5.3 & 7.3 & 5.9 \\
\hline Sub-Saharan Africa & 1.7 & 2.1 & 1.1 & 1.4 & 2.2 & 4.7 & 7.2 \\
\hline South Asia & 5.7 & 5.7 & 6.9 & 6.9 & 6.4 & 12.4 & 8.6 \\
\hline
\end{tabular}

Source: World Development Report, 1998.

its closer integration with the world economy, its higher rates of domestic savings and investment and its generally more impressive human development record than South Asia (with the significant exception of Sri Lanka). Even the growth of South Asia was significantly higher than those of other developing regions, such as Latin America and Sub-Saharan Africa, whose performance in the 1980s was dismal. Although the growth rates in Latin America have recovered in the 1990s, those of Sub-Saharan Africa still remain depressed at a little above 2 percent per annum.

The growth strategies of different Asian developing countries before the current globalisation era were predicated largely, on their resource endowments. Thus for example, the larger South Asian countries and China, endowed with a large population and a nascent industrial base, found it convenient to enlarge their domestic industrial sector mainly through import-substitution and catering for domestic demand. These larger countries did not confine themselves to importsubstitution in light labour-intensive manufactures, in which they could have become more efficient over time through learning by doing or through reaping the economies of scale with expanding domestic and external markets. Instead, they chose to extend import-substitution to intermediate and capital goods industries as well. This 
approach proved costly as the inefficiencies in the intermediate and capital goods industries were passed on to the consumer goods industry. On the other hand, countries with relatively small size and low product diversity found it expedient to produce mainly for the export markets.

The choice of secondary import-substitution by larger developing countries was influenced by balance of payments considerations, as well as by the motivation to acquire a comprehensive technological capability. The desire for rapid industrialisation and avoidance of the balance of payments constraint lay behind the adoption of the Mahalanobis-Feldman model, which assigned primary importance to the development of heavy industries. Other South Asian countries, such as Pakistan and Sri Lanka, facing similar balance of payments problems, did not follow the Mahalaonobian strategy to the letter, but still carried out extensive import substitution . These policies gave rise to a highly capital intensive, inefficient and technologically backward industrial structure and caused the agriculture sector to stagnate as a result of resource mobilisation policies of turning, very sharply on some occasions, the terms of trade against agriculture. Notwithstanding these weaknesses the South Asian countries, especially India, succeeded in building a sizeable industrial base.

In contrast, the development strategy pursued by the East Asian economies adopted more pragmatic policies towards the industrial sector (as well as a more supportive approach towards the agriculture sector). While state intervention in these countries was widespread, as in South Asia, it differed in being strategic, rather than pervasive. It was also more developmental and facilitatory and less preventive and interdictive. The typical East Asian state was a facilitator and promoter of the activities of the private sector and tried to "crowd in" rather than "crowd out" private investment. The state, unlike the private firm, was seen as capable of taking a longterm view and hence able to identify and promote "industries where income elasticity of demand is high, technological progress is rapid, and labour productivity rises fast" [Ojimi (1970)]. The East Asian governments have also paid relatively greater attention to the provision of physical and social infrastructure. Though the East and Southeast Asian economies have higher per capita expenditures vis a vis the South Asian economies, the differences in the proportion of GDP/public expenditure devoted to physical and social infrastructure in the two groups of economies is also striking (See Table 2).

Furthermore, there is a difference in the strategy adopted by East Asian countries in respect of social services and poverty alleviation. While the East Asian countries have tried to approach the problem in a more generalised manner, i.e., by expanding employment opportunities and by pursuing effective policies of human resource development, especially education and housing, the South Asian countries have adopted the more direct approach of subsidising food and social services, often 
Table 2

Social and Physical Infrastructure: Selected Indicators

\begin{tabular}{|c|c|c|c|c|c|c|}
\hline \multirow{2}{*}{$\begin{array}{l}\text { Public Expenditure } \\
\text { as a \% of GNP } \\
\text { on Health }\end{array}$} & \multirow[b]{2}{*}{1960} & \multirow[b]{2}{*}{$1988-90$} & \multicolumn{2}{|c|}{$\begin{array}{c}\text { Public Expenditure } \\
\text { as a \% of GNP } \\
\text { on Education } \\
\end{array}$} & \multirow{2}{*}{$\begin{array}{c}\text { Education as a \% } \\
\text { of Total Public } \\
\text { Expenditure } \\
1988-90\end{array}$} & \multirow{2}{*}{$\begin{array}{c}\text { Electricity } \\
\text { Consumption } \\
\text { per Capita (kwh) } \\
1988 \\
\end{array}$} \\
\hline & & & 1960 & $1988-90$ & & \\
\hline \multicolumn{7}{|l|}{ Early NIEs } \\
\hline Hong Kong & $\mathrm{n} / \mathrm{a}$ & 3.5 & $\mathrm{n} / \mathrm{a}$ & 2.7 & 15.9 & 4222 \\
\hline Republic of Korea & 0.2 & 6.4 & 2.0 & 3.7 & 22.4 & 2035 \\
\hline Singapore & 1.0 & 2.9 & 2.8 & 3.4 & 11.5 & 4821 \\
\hline Taiwan Province of China & $\mathrm{n} / \mathrm{a}$ & $\mathrm{n} / \mathrm{a}$ & $\mathrm{n} / \mathrm{a}$ & $\mathrm{n} / \mathrm{a}$ & $\mathrm{n} / \mathrm{a}$ & $\mathrm{n} / \mathrm{a}$ \\
\hline \multicolumn{7}{|l|}{ Later NIEs } \\
\hline Indonesia & 0.3 & 2.5 & 2.5 & 0.9 & 4.3 & 211 \\
\hline Malaysia & 1.1 & 1.6 & 2.9 & 5.5 & 18.3 & 1141 \\
\hline Thailand & 0.4 & 5.6 & 2.3 & 3.8 & 20.0 & 627 \\
\hline \multicolumn{7}{|l|}{ South Asia } \\
\hline Bangladesh & $\mathrm{n} / \mathrm{a}$ & 0.9 & 0.6 & 2.2 & 10.5 & 64 \\
\hline India & 0.5 & 3.2 & 2.3 & 3.2 & 8.5 & 299 \\
\hline Nepal & 0.2 & 0.7 & 0.4 & 2.9 & 10.8 & 36 \\
\hline Pakistan & 0.3 & 4.5 & 1.1 & 3.4 & 5.0 & 351 \\
\hline Sri Lanka & 2.0 & 2.3 & 3.8 & 2.7 & 8.1 & 169 \\
\hline
\end{tabular}

Source: Human Development Report 1993, pp. 158-159 and 164-165; and UN ESCAP, Economic and Social Survey of Asia and the Pacific 1990, pp. 133 and 150.

mainly in the urban areas. The generally poor record of social indicators in South Asia is also attributable to the political economy of public expenditure allocations which is largely biased in favour of the elite and urban middle classes rather than being targeted towards the poor. Thus while primary education was starved of funds, public investments were lavished on higher education, with stress paid more on the number of graduates produced rather than on the quality of education imparted.

A major adverse consequence of this neglect of human resource development is the deferment of a demographic transition, resulting in high rates of population growth and the translation of modest economic growth performance into poor growth in per capita income [Lucas (1993)]. The human development indicators of South Asian countries, with the exception of Sri Lanka and parts of India, such as Kerala, compare very poorly with those of East Asian countries. Some of these differences are in the nature of differences in initial conditions in that human resource development especially literacy and education have always been high in the East Asian countries than in others. However, the differentials in human resource development have also been the consequence of policy interventions in East Asia and, mutatis mutandis for lack of such intervention in South Asia.

For many years East/South-East Asian countries received universal kudos for being the fastest growing economies in the world. Their remarkable achievement in 
sustaining a high rate of economic growth over a long period was significantly fostered by their active participation in the globalisation process. This enabled them to take advantage of the increasing opportunities for using trade as an engine of growth and for accessing external capital and technology. However, enhanced participation in the globalisation process brings with it certain risks. These risks include frequent changes in the rules of the game which often impinge adversely on the autonomy of national governments to frame policies best suited to their country's circumstances. Fortunately, for these countries these rules, in the framing of which developed countries have a much larger say, were not too intrusive during their period of high growth.

In the 1990s, however, the worldwide liberalisation of trade and capital flows has considerably limited the room for independent national policies for development and are being increasingly forced to pursue policies cast in a standardised mould. As a result, not only many of these countries themselves have become victims of the risks of globalisation, their appeal as role-models for development has begun to lose its lustre. For many developing countries, the dream of becoming the next Asian tiger has now been replaced by the nightmare about becoming the next victim of a virulent strain of Asian flu.

The current East Asian crisis, which was triggered by the massive devaluation of Thai Baht in July 1997, differs from several previous currency crises in a number of fundamental respects [Krugman (1997)]. Since most early warning mechanisms were focussed on features which had been observed in past crises they failed to pick this one up. The key feature in this regard is the fact that the crisis was a private sector, not a public sector problem and that there was no significant public deficit or debt build-up in these cases. Further, the key private sector variable was investment growth, not consumption growth, so that widening current account surpluses were not seen as problematic.

\section{TECHNOLOGY AND ASIAN DEVELOPMENT STRATEGIES}

Growth and technological change have been a major preoccupation of economics since the days of classical economists such as Adam Smith, David Ricardo and Karl Marx. Since the late 1950s a large body of research undertaken by economists has tried to unfathom the complex relationship between economic growth and technical change. Empirical results by Solow (1957), not only confirmed the hypothesis of earlier economists that technical change implied a shift in the production function, rather than a movement along it, but also produced the landmark result that more than 80 percent of growth in labour productivity was owing to technical change, rather than growth in factor supplies. Since then considerable effort has gone into developing the concept of technical change within 
the production function framework and into modifying the treatment of technical change as endogenous (or embodied in factor inputs) rather than exogenous (or disembodied) factor.

\section{Hardware vs. Software}

In the past, technology was seen largely as being embedded in physical capital consisting of physical infrastructure and machines, equipment and structures in production plants and service providing organisations. These constituted the "hardware" of economic growth because, once in place, the technology implicit in the machines and other fixed structures rigidly determined particular patterns of activity, which cannot be changed without physically replacing the machines or structures. In recent years, however, the pendulum has been swinging away from "hardware" towards "software" issues of technology development, such as human and institutional development.

The role of human capital as a carrier of technology complementary to that embodied in physical capital, is now widely accepted. Lucas (1993), [Amsden (1989)] a Nobel laureate succinctly records the dethronement of physical capital accumulation by human capital as follows: "The main engine of growth is the accumulation of human capital—of knowledge — and the main source of differences in living standards among nations is differences in human capital. Physical accumulation plays an essential but decidedly subsidiary role. Human capital accumulation takes place in schools, in research organisations, and in the course of producing goods and engaging in trade. Little is known about the relative importance of these different modes of accumulation, but for understanding periods of very rapid growth in a single economy, learning on the job seems to be by far the most central”.

The importance of human capital has in recent years been emphasised in the Human Development Reports issued by the United Nations since the early 1990s, under the direction of the late Mahbubul Haq, who had originally agreed to address this Conference. The award of the Nobel prize this year to Professor Amartya Sen is also partly in recognition of the importance of human development, especially education, on which much of his more recent research has been focused. This year's World Development Report by the World Bank as well is devoted to Knowledge and Development. However, there are considerable disparities in both "hardware" and "software" of technology across Asian countries as shown in Table 3.

\section{PATTERNS OF TECHNOLOGY: DEVELOPMENT IN EAST ASIA}

The technological paradigm relevant for the East Asian economy is that of a "late industrialising" economies. Both the first industrial revolution in Great Britain 
Table 3 
which was largely driven by a series of technological changes, and the second industrial revolution in continental Europe and the United States a century later, were based on a new wave of innovation and in the case of the latter, the exploitation of the economies of scale. However, the defining feature of late industrialisers in the second half of the twentieth century has been not only borrowed technology but learning-by-doing. The received theory for the success of East Asian economies has been the existence of lower wages in them that upset higher productivity in the more developed countries but this has been shown to be insufficient to explain the success of East Asian countries in the export of manufactures to the developed world. The underlying superiority of these countries consisted more in the better organised production facilities, superior infrastructure, production and equipment. As shown by Amsden (1991), in East Asia subsidies were given to industries "according to the principle of reciprocity, in exchange for concrete performance standards with respect to output exports and eventually, $\mathrm{R}$ and $\mathrm{D}$. Late industrialisations requires a high degree of discipline of labour but what distinguished East Asia was not just discipline of labour but also its ability to channelise capital into priority areas of production. In all successful late industrialising countries the strategic focus of the firm centres on the shop floor as that is where borrowed technology is made to work. The success in the shop floor has been largely due to such institutional factors as relatively narrow earnings gap between managers and workers, high levels educational of the workforce and a high share of performance based bonuses in earnings. The business enterprises in East Asia are generally widely diversified and have defused "best practice management techniques" to a number of industries.

The role of the state in East Asian economies has varied during its industrial transition from import substitution to export promotion and high technology phases of development. Typically the role of the state has been strongest during the import substitution phase while the private sector has played an increasing role in the latter phases of development [Rhee (1988)].

More detailed descriptions of the technological progress of East Asia are catalogued in Hobday (1995), who discusses in detail the institutional framework and business alliances through which the step-wise climb up the technology ladder was realised in these countries, especially in the area of electronics. However, Hobday is prescient enough to point out that their strength lies in "low-cost, high-quality production engineering, rather than software or R and D" and that they are "conspicuously weak compared with Japan and other OECD economies".

Hobday's book carefully documents the "painstaking and cumulative process of technological learning" through which firms operating in East Asia rose up the technology ladder. He does not find much evidence of leapfrogging: "much latecomer learning took place in a field which could be described as pre-electronic: mechanical, electro-mechanical and precision engineering activities, for example. Competencies tended to build upon each other incrementally, leading to advanced 
engineering and software.” Hobday's account of technical progress in East Asia through extended learning by firms is also supported by generalised accounts of the process of technological capability acquisition [Lall (1997) and Nelson and Pack (1998)]. The crucial task is that of building up various human and organisational skills in the industrial workforce.

Nelson pays particular attention to the case of Taiwan and Korea and points out that though there are differences in the particular strategies adopted, some strong similarities show up between these countries. First, they both have broad and deep industrial structures unlike most other developing countries. Second, the industrial drive was partly a spin off from the effort to develop military capability. Third, the strong emphasis on education was crucial in providing the educated workforce necessary to support the transition to products of increasing technological complexity.

If the essence of economically significant human capital is the mastery of technology, then the latter is mainly a learned skill [Nelson (1997)]. Young and Krugman appear to assume that the technology embodied in imported capital goods merely resides in the machines and has little effect on production workers, the company or society Lall (1990) shows that this is very far from the reality.

At a given level of technology; a firm needs to have available to it skills and knowledge up to one or two steps below that of the target technology for it to be successfully undertaken, even if the associated capital equipment is imported. In learning to operate particular machines at internationally competitive levels of productivity, workers and firms raise themselves to commensurate levels of technological mastery. That is how human capital is built up. The above point is a consequence of the key role of learning under competitive pressure, or step-wise upgrading of skills and knowledge in building technological capability. Obviously the more complex the technology, the more time, effort and investment needed to indigenise the it.

Complementary organisational changes and business management practices also contribute significantly to aggregate productivity. The level of organisation and management is also, in a broad sense, a part of the technology of production and identified as a part of the "software" of economic growth. Lall (1997) shows that a large part of the building up of technological capability in a nation occurs within firms through organisational learning. The recent Asian financial crisis partly reflects the lack of balance between the soft and hard components of technology development.

In contrast to East Asian countries, South Asian countries have given more emphasis on scientific research than on technological accomplishment, with the possible exception, in case of India and Pakistan, in the nuclear field, which is motivated in order to achieve military rather than industrial or economic objectives. 
Thus while both countries, especially India, have produced high calibre scientists and even Nobel laureates, they have not succeeded in significantly improving the educational and skill levels of their labour force. Their educational system has remained elitist and has generally excluded the poor who form a higher proportion of the population than in East Asia.

In recent years, however, India has demonstrated a clear and growing capacity in service-sector exports based on information technology (IT) is now well-recognised. The Global Competitiveness Report of 1998 confirmed the high international opinion of India's engineering and scientific capacities, the products in part of India's long-term investments in the Indian Institute of Technology (IIT). India's prowess has been most evident in the software sector, where worldclass programmers operate in technology centres such as Bangalore, Delhi, Mumbai, and Chennai. Operating through satellite links, Indian programmers are providing IT support to U.S. and European firms in areas ranging from software development and maintenance, back-office operations, data transcription and transmission, telemarketing, and other related areas. Software exports have been growing around 50 percent per year in recent years, reaching an estimated \$1.75 billion in fiscal 1997-98, or roughly 5 percent of merchandise exports, a proportion that is likely to rise significantly in the years ahead (by some estimates to around 10 percent in the year 2000). Around 10 percent of Microsoft's worldwide programmer workforce is Indian.

Here, as in labour-intensive exports, Indian government policy could do much more to spur export growth. On the plus side has been the government's long-term commitment to the IIT. More recently has been the government's support for Software Technology Parks (STPs), in Bangalore, Pune, and other cities, which are the IT-industry equivalent of the EPZs in manufacturing industries [Bajpai and Sachs (n.d.)].

There are serious downsides, however. The continuing state monopoly in international telephony as well as in internet provision within the Indian market seriously raise the costs of telephone and IT services in India, and will do considerable damage in India's international competitiveness in the IT sector unless rectified. India's telephone density is abysmally low (See Table), at around 1.3 per hundred in 1995, compared with around 62.6 per hundred in the United States. Physical infrastructure for data transmission within India (e.g. fibre optic cables) remain underdeveloped despite some recent progress. Restrictive policies on FDI have kept international chip makers out of India, and have indirectly raised the prices of PCs in the Indian market. With a more liberalised and competitive environment, however, India's strengths in IT is likely to become an important bulwark of export growth. 


\section{GLOBALISATION: A NEW TECHNOLOGICAL PARADIGM}

There is broad consensus that trade and broader economic integration with the outside world significantly influence the upgrading of technologies in less developed countries. Does globalisation lead to technological upgrading in developing countries or does it result in a dependency relationship forcing them to specialise in low skill products with a poor technological content? This is a major issue which has been debated by development economists in recent years, especially in the context of export-led growth of East Asian economies. The question is discussed in somewhat greater detail in the next section.

There has been a major qualitative change in the paradigm affecting the transfer of technology. In the past, technology transfers were based on such products as steel, motor vehicles, and heavy machinery-items for which sizeable proportions of production costs reflected the value of raw materials and the sheer manual labour required to manipulate them.

Since then, trends toward conceptualisation have focused today's views of economic advancement increasingly on downsized, smaller, less “concrete" evidence of output, requiring more technologically sophisticated labour input.

The process of conceptualisation in output seems to have accelerated in recent decades with the advent of inventions such as the semiconductor, the microprocessor, the computer, and the satellite. There are two strings of transmission between trade and diffusion of technologies [Navaretti et al. (1998)]. The first one depends on the pattern of specialisation of the country in question. Learning is faster if the country specialises in goods with higher learning potential, both in terms of learning by doing or deliberate learning investments. Goods with higher learning potential are generally more technologically sophisticated goods, as measured by production technology, product quality or product varieties. Thus, trade will induce technological upgrading if opening up countries face a higher incentive to specialise in high tech products than in autarky.

However, technological upgrading is not just based on domestic resources. The second string of transmission is linked to the new potential sources of technological inputs opening up under free trade. Some of these technological inputs can be deliberately purchased (new machines, foreign investments, skilled personnel) and others are acquired through spillovers, by trading with more technologically advanced partners, by gathering information in foreign markets, by learning from sophisticated imported goods. Of course, these two strings are intertwined, in that the easier and the cheaper the imported technology the more likely are countries to specialise in high tech products. 
Trade affects the choice of the investment in learning (investment in schooling or specialisation in products with high learning potential) but the learning process takes place at home, without using foreign inputs. Interaction between countries provides great opportunities for learning. Trade is an obvious channel. It is possible to import new varieties of inputs and all types of foreign technologies. There is more exchange of information. It is possible to learn how imported products are made with reverse engineering. Foreign investments open up similar channels for learning. If they are complementary to trade, as in the case of vertical investments, both trade and investment will interact to produce a virtuous nexus to reinforce the learning process. Economic integration generates learning processes, which are partly intentional and accounted for by the market and are partly unintentional spillovers or external economies. ${ }^{2}$

Leading multinationals construct international production networks (IPN), as they need quick access to lower-cost external capabilities that are complementary to their own competencies. In general multinationals are found to have positive spillovers on productivity of local firms, although the magnitude of spillovers is positively affected by the absorptive capacity of local firms. Equally, FDI are found to enhance the export performance of host country firms, by providing access to foreign markets, and helping them in the marketing distribution and servicing of their products in the international market.

\section{IS TECHNOLOGY THE CULPRIT?}

A variety of explanations have been advanced so far for the sudden change of fortunes in the East Asian economies during the last year and a half ${ }^{3}$ [Radelet and Sachs (1998) and Taylor (1998)]. Most of them concentrate on the financial structure and macromanagement issues. However, this section will concentrate on supply side issues which are more closely linked to the question of technological development and its role in the growth process. One of the earliest critiques of East and Southeast Asian growth—indeed at a time when the euphoria about East Asian growth was at its highest and when few had any inkling of the 1997 crisis - centred on the productivity growth record and the "excessive" use of capital in these economies.

Krugman (1994), quoting the work of Young (1995) and Kim and Lau (1994), likened their capital intensive growth to that of the Soviet Union. He pointed out that "if growth in East Asia has been primarily investment driven" then it was likely that "capital piling up there is beginning to yield diminishing returns".

${ }^{2}$ Blomstrom and Kokko (1996), surveys the research on the role of foreign investments and the link between imported technological inputs and performance at the micro level.

${ }^{3}$ For a comprehensive review, [see, Corbett and Vines (1998)]. 
Krugman's article has spawned a lively controversy about the underlying factors of growth in the East Asian economies centring around the debate of total factor productivity, a measure which shows how efficiently factors of production are combined to produce output. ${ }^{4}$ The measure suffers from many serious conceptual and empirical problems and has not aroused universal acceptability among economists.

Krugman's critique of East Asian growth also raises the question whether high growth rates based primarily on high rates of capital accumulation (East Asian economies save from a third to two-thirds of their GDP) is sustainable in the long-run and whether these countries have should pay more attention to the state of art technology available to them rather than devote resources to the development of new technologies. In short, Krugman and others see the Asian miracle as being based on "perspiration" rather than "inspiration". Krugman conjectured that growth was bound to slow down soon as Western levels of capital intensity are approached. The recent financial turmoil and its repercussions on growth in Asia can be seen as a confirmation of Krugman's hunch.

Appendix Table 4 compares estimates of TFP growth in different studies of Asian growth. Most are consistent with the view that the contribution of capital growth has been significantly greater than TFP contribution although the pattern is more striking in some countries and time periods than others.

The core of the TFP debate centres around the interpretation of the rapid increases in capital per worker which took place. In neo-classical theory capital intensification is regarded as an automatic and effortless shift along a well known global production function. In contrast, "revisionists" stress the effort which is necessary to master technologies that might not be new to the world, but are unknown to the countries introducing them. Viewed this way, capital intensification is not a simple movement along a prevailing production function, but a search for an enlargement of the set of production possibilities. Successful absorption of new technologies, and investigation of new products and new markets requires a growing group of skilled workers and entrepreneurs who learn about and learn to master new technologies already in use in more advanced countries.

It is still an open empirical question whether productivity growth, and returns to capital, have been low for some time, or have been high but falling. Krugman cited the evidence of capital outflow from the region as evidence that returns have been low (and would presumably claim capital inflow since the mid-1990s as evidence of a bubble). Radelet and Sachs (1998) cite OECD data that the "rate of return on capital in Korea declined gradually from around 22 percent in the mid 1980s to about 14 percent in 1994.

In Singapore, a comparable indicator - the rates of return on US foreign direct investment-fell from 27 percent in the late 1980s to 19 percent in the mid-1990s. In

${ }^{4}$ For a critical review, [see, Chen (1997)]. 
Hong Kong and Taipei, China rates of return fell from around 21 percent to 15 percent. While these declines do confirm the neoclassical prediction of declining returns to investment, and are consistent with the rapid accumulation of capital documented by Young...the important point is that they are still well above the worldwide average returns on US foreign direct investment of 11 percent.”

In the context of the present crisis Krugman describes the problem as one of a short term boom "papering over the cracks" of fundamental problems in Asia. However, the puzzle is that despite low and falling rates of return to investment, implied by the TFP data, capital flowed in to the region and domestic investment continued at high rates of growth for more than two decades, which can hardly be called a "bubble". When the boom subsequently broke the fundamental fissures open up. Radelet and Sachs dispute this notion.

In discussions on East Asian growth, Young and Krugman, alongwith many others, tend to focus more on TFP than on average labour productivity, where the East Asian record is indisputably strong. The two measures need to be treated in conjunction with each other as complementary indicators of a country's economic progress. Aggregate labour productivity and its growth are the most useful measures of the level and changes in economic welfare. Total factor productivity (TFP) is a measure of economic efficiency, based on how well inputs are used to generate output. The two can not be separated in discussions of a country's economic success or failure. If both move in the same direction, there is little cause for concern, except about the speed of the change. But even if the TFP does not rise and average productivity does, there should be some cause for satisfaction, though not for complacency.

The idea of very low technical progress in East Asia conveyed by the TFP data also defies both commonsense and manifest reality. As Professor Stiglitz (n.d.) notes, "Any visitor to the cities and factories in East Asia comes away impressed by the enormous technological progress in the last decades. The Young, Kim, Lau et al. results do not seem to be very robust. When a country is accumulating capital rapidly, small changes in the estimate of the capital share can result in a large shift in estimates of the contribution of total factor productivity."

Besides casual empiricism, there is considerable evidence that Korea, Taiwan, Singapore and Hong Kong, have achieved considerable technological progress in a number of specialised areas or production niches. Among the most notable and widely known are consumer electronics, computers and integrated circuits (ICs), automotive products, automation in manufacturing, telecommunications, aerospace and military, medical electronics, power and energy and transportation. By 1991, they had shifted well beyond the mere assembly of components to some high value added, high technology manufactures as well. 
A recent study by Timmer (1998) provides a revealing comparison of manufacturing productivity levels in China, India, Indonesia, South Korea and Taiwan with the US as the reference country for the period 1963-1993. According to the study, South Korea and Taiwan showed prolonged "catching up" in labour productivity with the US, whereas the other countries had long periods of relative stagnation. This is reflected in relative performance of seven detailed manufacturing branches. Physical capital per hour worked in the Asian countries is still well below the US level and there are abundant opportunities for further capital intensification. Relative total factor productivity levels in South-Korean and Taiwanese manufacturing are much lower than in the US in all manufacturing branches. The same is true for India and Indonesia compared to South Korea and Taiwan. Hence, the author concludes, “ late industrialisers do not automatically benefit from the increasing global pool of technologies”. The study also shows that TFP results at the aggregate level, on which Krugman places primary reliance, could be substantially different from those at the disaggregated industry level.

While the performance East-Asian countries in the technological field is not as unsanguine as depicted by Krugman and other protagonists of low total factor productivity thesis, there do seem to be serious weaknesses in the technological base and the institutional structure of East Asian countries which could adversely affect their long-run development as well as their recovery from the present crisis. Some of these weaknesses are revealed in a study [Ernst (1998)] of Korea and Taiwan, the leading late industrialisers of East Asia. In particular, the study focuses on Korean electronic industry which was the leading sector in the high rates growth of Korean exports. Ernst identifies three major limitations to catching up process in the Korean electronics industry. These are; (a) a narrow domestic knowledge base; (b) a narrow and a sticky product specialisation; and (c) a high imports dependence. These limitations have become more serious in the face of the financial crisis that hit Korea and other East-Asian countries towards the end of 1997.

An OECD review in 1995 concluded "the country can no longer afford simply to import technology - the foreigners are more and more reticent to introduce on concessional terms - and will have to raise the value-added and technological intensity of what it produces [OECD (1995)]. Since then the additional constraint of a shortage of foreign exchange has made it even more imperative for Korea to broaden its knowledge base which, in turn, has been limited by such factors as the lack of a critical mass of $\mathrm{R}$ and $\mathrm{D}$, inefficiency in corporate technology management and public innovation system.

In the past, Korean electronic firms had little motivation to invest in R and D. However, with the emergence of other competitors with lower labour costs, Korean electronics industry lost its comparative advantage in low technology products and the need for increased $\mathrm{R}$ and $\mathrm{D}$ expenditures became apparent in order to move to higher value-added products where imported technology is either too expensive or 
not easily available. Although Korea's private $\mathrm{R}$ and $\mathrm{D}$ spending as a ratio of total sale increased from 0.36 percent in 1976 to 2.5 percent in 1995 which is less than half of the current $\mathrm{R}$ and $\mathrm{D} /$ trade ratios of US and Japanese manufacturing companies. Korea's per capita R and D expenditures of \$176.2 (in 1993) lagged well behind those of Japan (\$762.9 in 1992) and the US (\$540.9). The extremely tight budgetary constraints imposed by the IMF bail-out package for Korea implies that $\mathrm{R}$ and $\mathrm{D}$ expenditure will be curtailed rather than increased.

Korea also lagged behind in patent registrations major OECD countries in patent registration. The problem in Korea is not only with the low level of R and D expenditures but poor management of technology development. Thus, while Korea spent more than twice the amount for R and D compared to Taiwan, the number of patents granted to Koreans by the US in 1992 was only 538 or less than half compared to 1252 patents granted to Taiwanese.

The private sector now spends more than 80 percent of Korea's total R and D expenditures. However, private $\mathrm{R}$ and $\mathrm{D}$ has a very narrow focus. Most of it is geared to development rather than research, specially process re-engineering and product customisation. The main problem with the R and D sector in Korea is a mismatch in the allocation of funds and equipment. While nearly 80 percent of the Government civilian $\mathrm{R}$ and $\mathrm{D}$ funds go to government research institutes (GRIs) - a much higher proportion than given to such institutes in France and Japan, the two countries where the government traditionally has played a strong role in the national innovation system, Korean universities which employed 76 percent of Ph.D holders receive less than 11 percent of government civilian $\mathrm{R}$ and $\mathrm{D}$ funds. Further weakness of the Korean innovation system, paradoxically enough relates with established educational system. While in the past the system's heavy focus on training mid-level managers, engineers and technicians served it well, the present needs for research product design and market development in a competitive world are not adequately fulfilled by it. Korea faces a crisis in its higher education as its reliance on the formal education system with heavy emphasis on conformity, memorisation and lack of creativity has made it anchronous.

Korea's semi-conductor industry also suffers from a very narrow product range and a high dependence on imports. While it exports more than 90 percent of its total semi-conductor output, it imports more than 87 percent of its domestic demand for other semi-conductor products. Such an extreme imbalance between supply and demand makes its very difficult to broaden and deepen the forward and backward linkages within the electronic industry and the economy generally. Indeed, Korea's semi-conductor industry can be treated as a modern version of the classical mono product primary export enclave, with minimal linkages with the domestic economy. ${ }^{5}$

${ }^{5}$ Korea needs to import 70 percent of its total inputs for semiconductors production (40 percent from Japan and 20 percent from the United States). As for the production equipment, 90 percent have to be imported, with 50 percent originating from Japan. 
As a result of its inability to upgrade its technology through $\mathrm{R}$ and $\mathrm{D}$ and move into more sophisticated products, Korea has undergone a perverse change in the destination of its electronic exports away from the demanding American and European markets and towards an increasing reliance on emerging market countries of East Asia, Latin America, Eastern Europe and Russia.

The high import dependence of the Korean economy, which arises largely from the high import-intensity of its electronics industry, constitutes a fundamental barrier to sustained industrialisation. Korea's electronics industry heavily depends on imports of key components, subassemblies and production equipment. As long as this structure is preserved, trade deficits will continue to expand and exchange rates will come under downward pressure, even if economic growth rates rise. This has been an important element underlying Korea's high vulnerability to the crisis of international capital and currency markets.

It is also significant to note that Taiwan, which has been less severely affected by the Asian 'contagion' than Korea, often regarded as its twin, partly because it followed a different pattern of technological specialisation and industrial organisation. ${ }^{6}$ While in Korea, the dominant form of industrial enterprises, the chaebols, have typically used octopus-like unrelated diversification as a short-cut to rapid market share expansion, the small and medium enterprises, the modal form of industrial enterprise in Taiwan, have concentrated on deepening their involvement in a particular sector or group of related products. Their without much concern for the depth of the production system that can be generated by such shallow forms of diversification. As a result, the Korean companies were unable to accumulate systematically a broad range of technological capabilities for a given set of products. It also has also left very little scope for an upgrading into higher-end market niches where premium prices could be reaped. Finally, this opportunistic form of unrelated diversification has precluded a shift to technology diversification.

\section{LESSONS FOR THE FUTURE}

The robust development of the Asian economies in the past two decades has been seriously marred by the self-doubt created in the region by the Asian financial crises of the past year and a half about the future prospects of the region. It has forced us to reconsider the perceptions about how technology affects economic growth and how both are shaped by globalisation. Among the important lessons that emerge from the experience of successful countries in the region are:

${ }^{6}$ There were also other differences between the initial conditions and policies of the two countries, especially the fact that Taiwan had much higher foreign exchange reserves ( $\$ 86$ billion) and a much lower foreign debt (only \$100 million) at the time of the crisis than Korea (\$17 billion and \$230 billion, respectively). For these and other details, see Ranis, Miracles that do not cease, Financial Times, 19 February, 1998. 
(i) Technological specialisation determines export success: the more a country focuses on higher-end, R and D-intensive products, the more it is expected to experience sustainable export growth and increasing export revenues.

(ii) Catching-up requires an active state and a set of institutions, incentives and policies that can mobilise the necessary resources, and

(iii) Accumulation of capital matters, but it needs to be complemented with the capacity to learn, to assimilate and to innovate.

(iv) In any event, technological progress is not reversible. We must learn to live with it. The search for Swadeshi, Islamic or otherwise culturally kosher technologies will lead us to nowhere in this globalise world. It is of course quite legitimate to use technologies within the cultural, social and other desirable parameters of a country.

Globalisation has also underlined the need for developing new technological paradigms which will enable a country to move up the technology ladder and constantly watch out against being trapped in a dead-end. Technological upgrading has to be a continuous process undertaken along with the restructuring of the economy in the wider sense. Mere adoption of new technologies which may yield high payoffs in terms of output and exports will not serve the purpose. In the context of the current East Asian crisis, the region now faces a fundamental dilemma: the crisis has dramatically increased the need for industrial upgrading, while at the same time reducing its chances of success as the urgent need is the revival of the economy rather than long-term restructuring.

East Asia's success in recent decades had been conditioned by partial restructuring of the economy epitomised by the "flying geese" model, envisages a continuous shifting of comparative advantage from developing countries at a higher stage of development to those at a lower stage [UN-ESCAP (1990)]. This is achieved by an increasing complementarity as the former vacate their niches in the production and export of relatively less sophisticated industries to the less developed Asian nations. However, this model no longer works as effectively as it did in the past, if only because the leading goose, Japan, has become a dead duck [Bergsten (1997)].

At a broader level, a radical paradigm shift is needed, as East Asia has reached the limits of the old export-led industrialisation model with its emphasis on standardised mass production. Moving beyond these limits will require a number of fundamental changes in the development model. Of critical importance is the creation of a broad-based and diversified knowledge base for technology diversification, especially with regard to product design, market development, the production of key components and the provision of high-end knowledge intensive support services. Strengthening the financial and technological capabilities of domestic small- and medium-size enterprises (SMEs) is a second element of such a paradigm shift. 
Innovative SMEs are an essential prerequisite for flexible domestic support industries. Thirdly, government, business and labour, there is an urgent need for establishing a new social consensus, with the help of all the principal actors in the economy, including those adversely affected by restructuring, and for improving the society's learning efficiency.

Finally, one of the most critical issues that the Asian countries need to face in the coming years is a redefinition of the link between local capability formation and international linkages. Globalisation has made it impossible for local capabilities to exist in isolation: they are rapidly becoming internationalised, either through acquisitions or through the increasing power of global customers .This requires a major shift in strategic priorities, away from, though not at the expense of, an almost exclusive focus on the establishment of "national" institutions and linkages. However, in the final analysis a country's development, including its technological development, is “...limited by the growth of knowledge within it”, regardless of whether such knowledge is created by national or foreign institutions.

\section{REFERENCES}

Amsden, A. H. (1989) Asia's Next Giant. South Korea and Late Industrialisation. New York: Oxford University Press.

Amsden, A. H. (1991) The Late-Industrialising Model and Greater Asia. American Economic Review 81:2 282-286.

Bajpai, Nirupam, and Jeffrey D. Sachs (n.d.) Strengthening India's Strategy for Economic Growth Development. (Discussion Paper.)

Bell, Martin, and Keith Pavitt (1993) Technological Accumulation and Industrial Growth: Contrasts between Developed and Developing Countries. Industrial and Corporate Change 2:2 and 2:4.

Bergsten, Fred C. (1997) A New Strategy for the Global Crisis, International Economics Policy Brief 98-7. Washington, D.C.: Brookings Institution.

Blomstrom, M., and A. Kokko (1996) Multinational Corporations and Spillovers. Note di Lavoro: Fondazione Eni Enrico Mattei, 20.96.

Chen, Edward K.Y. (1997) The Total Factor Productivity Debate: Determinants of Economic Growth in East Asia. Asian-Pacific Economic Literature 11:1 18-38.

Cooper, Richard, and T. N. Srinivasan (1995) Comments and Discussion on Paul Krugman Growing World Trade: Causes and Consequences. Brookings Papers on Economic Activity 1: 363-377.

Corbett, Jenny, and David Vines (1998) The Asian Crisis: Competing Explanations. Centre for Economic Policy Analysis New School for Social Research, New York. (CEPA Working Paper Series III, Working Paper No. 7.) 
Ernst, D. (1998) Catching-up, Crisis and Industrial Upgrading. Evolutionary Aspects of Technological Learning in Korea's Electronics Industry. Asia Pacific Journal of Management 15:2.

Hobday, Michael (1995) Innovation in East Asia-The Challenge to Japan. Aldershot: Edwar Elar.

Kim, J., and L. Lau (1994) The Sources of Economic Growth of the East Asian Newly Industrialised Countries. Journal of the Japanese and International Economies 8: 235-271.

Krugman, P. (1994) The Myth of Asia's Miracle. Foreign Affairs 73: 62-78.

Krugman, P. (1997) Currency Crises. Cambridge: Mass, Accessible through Paul Krugman's Homepage on the Internet: //web.mit.edu/krugman.

Krugman, Paul (1995) Growing World Trade: Causes and Consequences. Brookings Papers on Economic Activity 1: 327-362.

Lall, S. (1997) Technological Change and Industrialisation in the Asian NIEs: Achievements and Challenges. Paper presented at international symposium on Innovation and Competitiveness in Newly Industrialising Economies. Science and Technology Policy Institute, Seoul, Korea, May 26-27.

Lucas, Robert, (1993) Making a Miracle. Econometrica 61:2 251-272.

Navaretti, Giorgio Barba, Enrico Mattei, and Andrea Mattozzi (1998) Import of Technology and Export Performance. Paper prepared for the UNU-INTECH International conference on The Economics of Industrialisation, Lisbon 16-17 October.

Nayyar, D. (1996) Globalisation: The Past in Our Present. Presidential Address, Seventy-eighth Annual Conference, Indian Economic Association, Chandigarh, India.

Nelson, R. R., and H. Pack (1998) The Asian Miracle and Modern Growth Theory. World Bank, Washington, D. C. (Policy Research Working Paper 1881).

OECD (1992) Technology and the Economy The Key Relationships. Paris.

OECD (1995) Reviews of National Science and Technology Policy: Korea. Part II: Examiners’ Report, DSTI/STP 95:15, OECD, Paris, p. 5.

Ojimi, V. (1970) Japan's Industrialisation Strategy. In Japanese Industrial Policy. Paris: OECD.

Radelet, S., and J. Sachs (1998) The Onset of the East Asian Financial Crisis. Paper for USAID. (Mimeographed.)

Rhee, S. (1988) Recent Industrial Adjustments of Korean Economy and Underlying Policy Reforms. The Developing Economies 26: 222-246.

Solow, Robert (1957) Technical Change and the Aggregate Production Function. Review of Economics and Statistics 39: 312-320. 
Stiglitz, Joseph E. (n.d.) Sound Finance and Sustainable Development in Asia. Keynote Address to the Asia Development Forum. Manila, The Philippines.

Taylor, Lance (1998) Origins of Capital Market Crises. Centre for Economic Policy Analysis New School for Social Research, New York. (Working Paper No. 6.)

Timmer, M. (1998) The Economics of Industrial Structure and Innovation Dynamics. Centro Cultural de Belém, Lisbon. Paper prepared for UNU/INTECH International Conference on The Economics of Industrialisation. Lisbon, 16-17 October.

UN-ESCAP (1990) Restructuring the Developing Economies of Asia and the Pacific in the 1990s. New York: ESCAP.

Young, A. (1995) The Tyranny of Numbers: Confronting the Statistical Realities of the East Asian Growth Experience. Quarterly Journal of Economics 110: 641680 . 